\title{
Decision Support System Using Cloud-Based Moka Pos Application To Easy In Input In Orange Carwash Blulukan Flash N0.110 Colomadu
}

\author{
$1^{\text {st }}$ Ayu Sri Muryani, $2^{\text {nd }}$ Muqorobin \\ ${ }^{1,2}$ Institut Teknologi Bisnis AAS Indonesia Surakarta \\ ${ }^{1,2}$ Jl. Slamet Riyadi No. 361 Windan, Makamhaji, Kartasura, Sukoharjo, Indonesia \\ 1'ayufebrando@gmail.com, ${ }^{2}$ robbyaullah@gmail.com
}

\begin{abstract}
Orange Carwash is a car wash service business that has been running in 2018, Orange Car. The wash address that I studied is located at Jalan Adi Sucipto no.110 Blulukan Colomadu In running a car wash service business, Orange Carwash tries to provide services to customers, regarding inputting types of washing products, member entry, express washing promos, and payment transaction methods. The system used is still classified as manual. For the purpose of this research, it really helps companies in terms of promoting and introducing products to car wash consumers with a computerized system using the cloud-based Moka Pos application. The method in this research is through observation, interviews, documentation, and heritage studies (looking for references from books or journals). The system design is made with context diagrams, HIPO, DAD, input output design, hardware requirements analysis, software requirements analysis. By using online input, the cashier will find it easier to group the washing type product data, as well as compile accurate and efficient reports. The final result of designing an online car wash service information system, using the Moka Pos application, in the form of sales report recap data and the number of types of washing products, classification of types of washing products, and the washer name of each cashier, which will be designed by the car wash. Oranger Carwash.
\end{abstract}

Keywords - Washing Products, Services, Decision Support Systems, Moka Pos,

\section{INTRODUCTION}

Orange Carwash is a car wash that is served with satisfying results and the number of car wash customers is increasing, so it requires professionalism in terms of customer service. This encourages Orange Carwash to carry out various strategies to attract customers not only in terms of services but also in terms of administrative services (sales calculations), because both are inseparable systems [1].

Previous manual systems often caused problems including calculation errors, time in preparing reports, and data loss.

The researcher took the research title "Designing Service Information Systems at Orange Carwash" as a test whether the computerized system made it easier for cashiers to classify and classify products and price lists.

The solution in designing a car wash service information system on Orange Carwash uses the cloud-based Moka Pos application that makes it easy for cashiers to input car wash lists, and calculate daily sales, so that the resulting data is real and accurate.

\section{RESEARCH METHODS}

In obtaining data and information, a research method is needed. There are 2 types of methods, namely the data collection method and the system floating method. Data Collection Methods : The following data collection methods are as follows: Interview : Interviewing is a method that is done by asking questions or asking questions and answers to sources (Orange Carwash), so as to obtain data and information. Observation : Observation is a data collection method that is carried out by making direct observations by looking at and retrieving the required data in the place where the research is carried out. Literature study : Literature study is looking for references or theories needed through scientific books or journals that are related to problems in the car wash service design system. Systems Development Method : The following methods in system development are as follows: 1. System Planning : In the system planning stage, a needs analysis is carried out to define the system design starting from the flow, system architecture, display and data structure of the "Moka Pos" application. 2. System Analysis : Intelligent Stage, Tahal Design, Selection Stage (Choice), Implementation Stage (Implementation). 3. System Design : Application Design includes: Context Diagram, HIPO, DAD, Database Design, Input Output Design, Technology Design. 4. System Implementation : The implementation phase of this application includes software requirements related to Firebase databases and algorithms, hardware, PHP programming language, queries used, program development and testing and system testing that has been designed according to the needs of the "MokaPos" application user. 5. System Testing : There are 2 Testing Systems: Functionality Testing (Performance Testing) and Validation Testing (Validation Testing).

\section{RESULT AND ANALYSIS}

In the discussion, discussing the results of research in the form of system design as a whole are as follows:

\subsection{Computerized System Analysis}

System analysis is a process that must be carried out to determine a problem that must be faced. The system used by Orange car wash previously used a manual system, which could lead to inaccurate data, long recording, and the length of time it took to calculate sales. And for solutions to the old system, this agency requires technological developments to make it easier for cashiers to input a car wash service. This system requires a computerized decision support system using the "Moka Pos" application so that it can make it easier for cashiers to input product types, car 
International Journal of Computer and Information System (IJCIS)

Peer Reviewed - International Journal

Vol : Vol. 01, Issue 03, November 2020

e-ISSN : 2745-9659

https://ijcis.net/index.php/ijcis/index

numbers, car types, and prices, this also makes it easier for customers to make payments using chasless, as well as barcode scanners that can be used. do customer.

\subsection{System Design}

System design is a system design designed to describe the flow of a system. The following are the stages in system planning:

1. Contex Diagram

Contex Diagram (CD) for a car wash information system service decision support system:

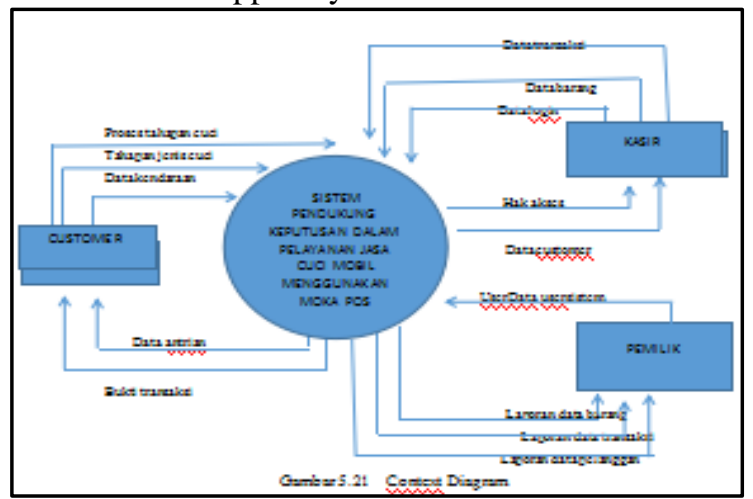

Figure 1.Context Diagram

\section{2. $\mathrm{HIPO}$}

HIPO (Input Process Output Hierarchy) is a system development tool and system documentation technique in programs. The most important goal of HIPO is to produce correct output and meet user requirements.

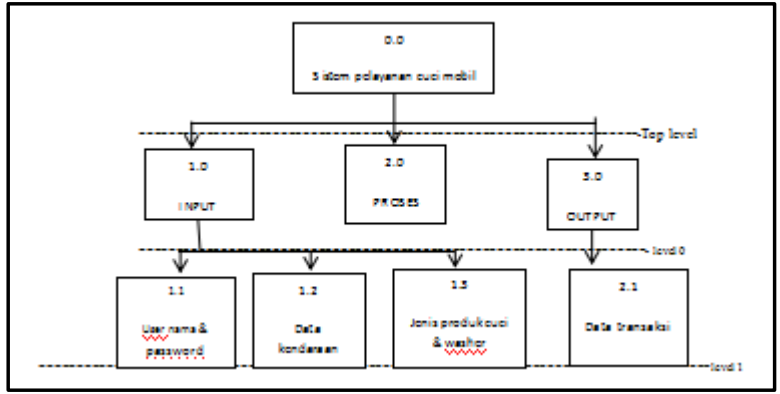

Figure 2. HIPO

\section{DAD (Data Flow Diagram)}

Data Flow Diagram (DAD) is a flow diagram that describes the flow from data to the system, DAD helps to understand the system in a logical, structured and clear way. The following is DAD level 0 for the SPK for car wash information system services:

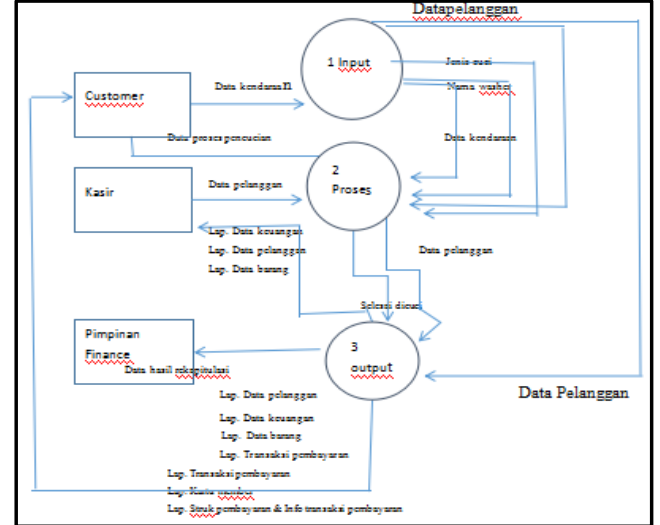

Figure 3. DAD (Data Flow Diagram)

\subsection{System Implementation}

Implementation of the system is the process of making a system in the form of designing a car wash service SPK application:

1. Display Input Menu login

This section describes the login process or the first step in opening the Moka Pos application. Users use email and password in the login process, the login data has been created for each cashier. So each cashier has a different email and password, so that in inputting the cashier there will be no problems / double input in inputting the results of the washing products selected by the customer. And when logging in and operating the system, the user must ensure that the internet network is smooth and there is no trouble signal.

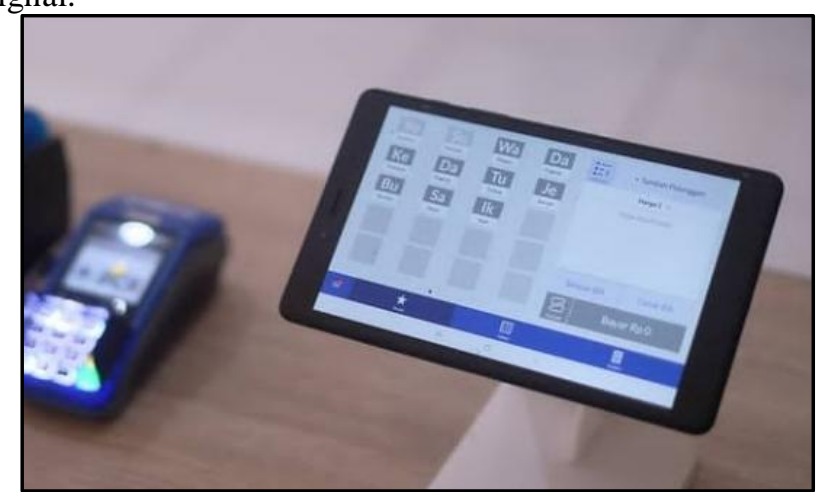

Figure 4. Menu Point Of Sale

\section{Display Custom Menu}

In this custom menu, we can enter special prices that are not listed on the menu options. Like when there is an attractive promo from Orange Carwash, of course there is a price reduction, and there are additional prices, such as washer tips or additional cash (adding car compound). 
International Journal of Computer and Information System (IJCIS)

Peer Reviewed - International Journal

Vol : Vol. 01, Issue 03, November 2020

e-ISSN : 2745-9659

https://ijcis.net/index.php/ijcis/index

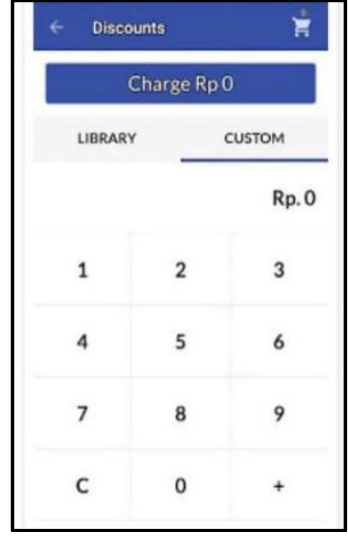

Figure 5. Display Custom Menu

\section{Payment Transactions}

This payment process, customers can do it by transacting various payment methods that have been integrated into the Moka Pos application. For example: payments using Dana, LinkAja, Ovo etc.

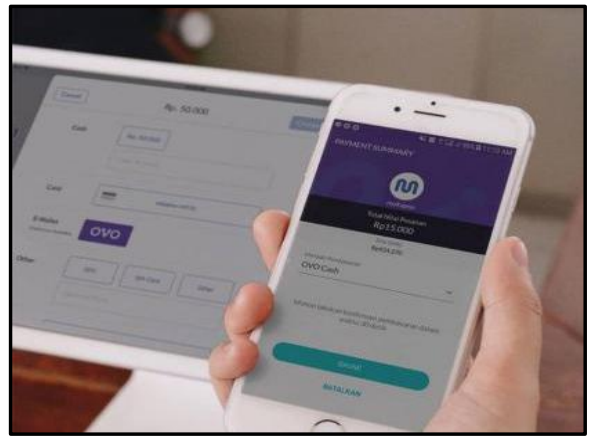

Figure 6. Payment transaction menu

\section{Send receipt page via SMS / Email}

Print purchases or receipts digitally via SMS or email. All customer data will go directly to the database every time we send a digital receipt, which can later be used for marketing promotions.

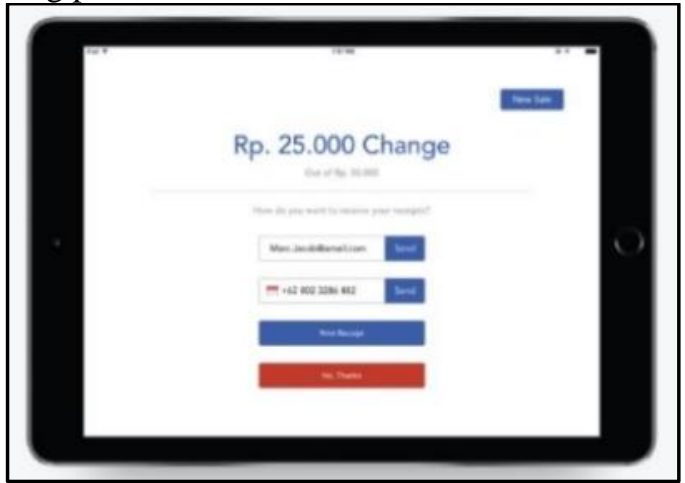

Figure 8. Display page of sending receipts via SMS or email.

Results of the Recapitulation at the Finance Manager: This section is the result of the washing product input process, which leads to the sales calculation. The recapitulation makes it easier for FM to conduct monthly evaluations in each of its branches and determine the amount of salary earned by employees, because the sales are accumulated properly by the FM.

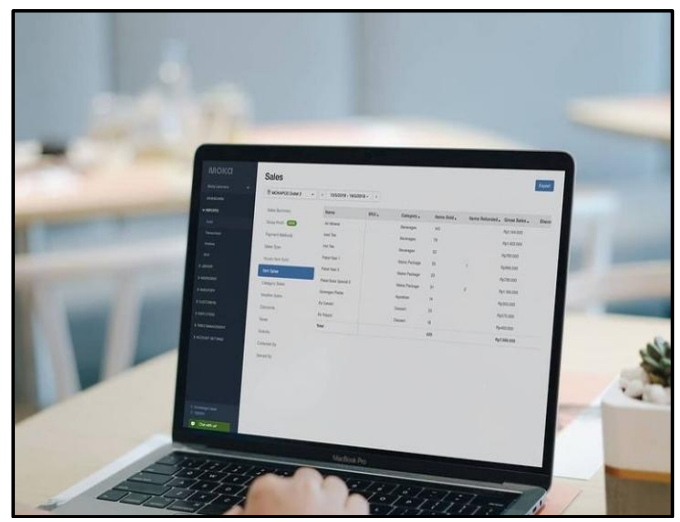

Figure 9. Recapitulation Results on the Finance Manager

\subsection{System Testing}

System testing is needed to determine whether the system that has been used is in accordance with what is expected by the head of the agency or not. In this chapter the authors use two methods of testing, namely functionality testing and questionnaire testing, all of which have been tested to determine the feasibility of a car wash service system using the Moka Pos application. Here are some tests compiled by the author:

Table 1 . Functionality Test

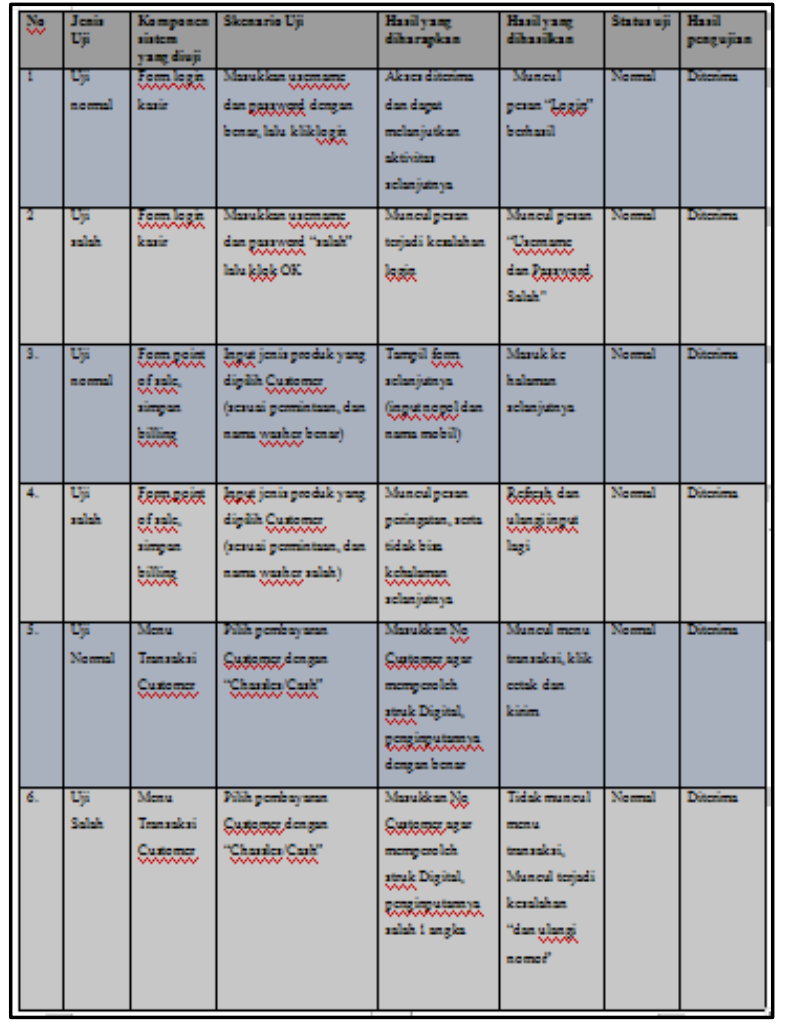

In the running of the new system, there are several SWOT analysts related to car wash type services, for inputting types of washing products using the Moka Pos application, namely as follows: 
International Journal of Computer and Information System (IJCIS)

Peer Reviewed - International Journal

Vol : Vol. 01, Issue 03, November 2020

e-ISSN : 2745-9659

https://ijcis.net/index.php/ijcis/index

From the SWOT analysis above, the car wash service system using the cloud-based Moka Pos application can be used and optimized properly, because it is effective and efficient to make it easier for companies to input the types of washing products, the number and classification of types of washing, as well as the sales calculations obtained. And for this system it is worth using for the next period.

There is an idea for agencies regarding the Moka Pos application system, that there is an expansion of the system that can be used for guestbook entry, to make it easier to inform promos about car wash products.

\section{CONCLUSION}

This section contains conclusions and suggestions in research, namely as follows: Conclusion : Based on the discussion conducted in the previous chapter, the conclusions are as follows: The existence of a new system of Decision Support Systems by applying all the criteria that can solve problems that occur in the old system. The old system for carrying out the recording process was still manual, resulting in imprecise and fast results. with the new system that uses a computerized system with a cloud-based Moka Pos application that can produce more precise, faster results and make solutions to problems in the old system. With the questionnaire test Strongly agree: $21.8 \%$, Agree: $52.5 \%$, Sufficiently agree: $19.5 \%$, Disagree less: $5.8 \%$, and Disagree: $0.4 \%$. We can conclude that the Moka Pos application is functioning properly. Validation testing is the process of evaluating software during the development process or at the end of the development process to determine whether this software meets specified biblical needs. testing the cashier application "MokaPos" with the input we can find out what types of washing products are used by the customer, and accompanied by payment methods and a predetermined price list of washing products. The existence of Performance Testing Testing is a general name used for testing that checks how the system is performing. This test checks the responsiveness, stability, scalability, reliability, speed, and user resources of the software and system infrastructure. Performance Testing has 2 types of categories, namely as follows : Font-end performance, Graphical User Interface (GUI) testing, functionality and usability of the MokaPos application system. Back-end performance testing, testing that checks from the server side or the Firebase database, this test is called Database Testing. Suggestions : Based on the above conclusions, the authors propose several suggestions that can be considered, It is recommended to periodically evaluate the product washing services used by the cashier to input the types of customer washing products, so that the functions and objectives of the system can be implemented optimally. With the Moka Pos application system, this system can develop and innovate more in designing the next system. There is maintenance of a system in order to minimize integrated accounts in other agencies or other hardware, so that the system is safe and not mistakenly used. Data entered into the program is expected to use the correct data After finishing using the program, efforts are made to back up the data, so that the database is stored properly. For the shortcomings of the system, the Moka Pos application does not yet include the Orange Carwash customer guest book, which will later be used for promotional media. One way to overcome these shortcomings is confirmation to CS Moka Pos so that the system is up to date. The Moka Pos application does have input of the customer's telephone number, but not for the guest book, but for printing digital receipts that are sent via SMS or email.

\section{REFERENCES}

[1] Verdianto, Yurisco and Elvo. 2015. Car Management Administration Information System. Faculty of Computer Science, Universitan Dian Uswantoro Semarang.

[2] Purnama, Chamdani. 2016. Management Information Systems. Global People. Jl Raya Brangkal 38 Mojokerto

[3] Jogiyanto (1999: 179). Analysis and Design of Information Systems. Page 2. Vol 4 No 1 - March 2016.

[4] Solihin, Ahmad, MySQL 5 From Beginner to Advanced, Achmatim. net. Jakarta

[5] https://www.firebase.com/features.html, accessed September 26, 2015.

[6] Muqorobin, M., \& Rais, N. A. R. (2020, November). ANALISIS PERAN TEKNOLOGI SISTEM INFORMASI DALAM PEMBELAJARAN KULIAH DIMASA PANDEMI VIRUS CORONA. In Prosiding Seminar Nasional \& Call for Paper STIE AAS (pp. 157-168).

[7] Utomo, I. C., Rokhmah, S., \& Muslihah, I. (2020). Web Based Distribution of Zakat, Infaq, and shodaqoh (Case Study Of Surakarta City Region). International Journal of Computer and Information System (IJCIS), 1(1).

[8] Muqorobin, Muqorobin, Siti Rokhmah, Isnawati Muslihah, and Nendy Akbar Rozaq Rais. "Classification of Community Complaints Against Public Services on Twitter." International Journal of Computer and Information System (IJCIS) 1, no. 1 (2020).

[9] K. Kusrini, E. T. Luthfi, M. Muqorobin and R. W. Abdullah, "Comparison of Naive Bayes and K-NN Method on Tuition Fee Payment Overdue Prediction," 2019 4th International Conference on Information Technology, Information Systems and Electrical Engineering (ICITISEE), Yogyakarta, Indonesia, 2019, pp. 125-130, doi: 10.1109/ICITISEE48480.2019.9003782.

[10] Muqorobin, M., Hisyam, Z., Mashuri, M., Hanafi, H., \& Setiyantara, Y. (2019). Implementasi Network Intrusion Detection System (NIDS) Dalam Sistem Keamanan Open Cloud Computing. Majalah Ilmiah Bahari Jogja, 17(2), 1-9.

[11] Muqorobin, M., Apriliyani, A., \& Kusrini, K. (2019). Sistem Pendukung Keputusan Penerimaan Beasiswa dengan Metode SAW. Respati, 14(1).

[12] Abdullah, Robi W., et al. "Keamanan Basis Data pada Perancangan Sistem Kepakaran Prestasi Sman Dikota Surakarta." Creative Communication and Innovative Technology Journal, vol. 12, no. 1, 2019, pp. 13-21. 